\title{
Antibacterial Activity from Different Parts of Capparis spinosa $\mathbf{L}$.
}

\section{Firas Abbas Al-Bayati}

Dept. of Biology / College of Education

\author{
Mohammed Taha Al-Jarjry
}

\section{University of Mosul}

$\begin{array}{cc}\text { Received } & \text { Accepted } \\ 6 / 9 / 2006 & 14 / 11 / 2006\end{array}$

\section{المالخص}

قم في هذه الدرلسة تحديد التأثير التبطي للمستخلصت الكحولي ة والكلوروفورمي ة

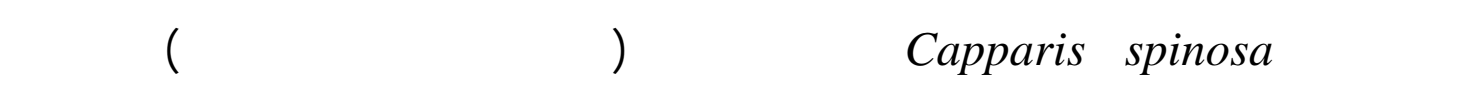

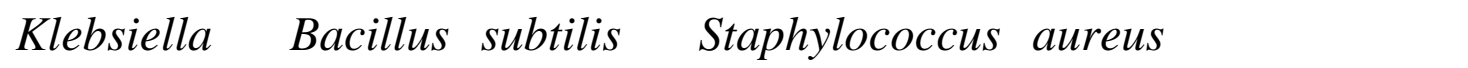
Proteus vulgaris Pseudomonas aeruginosa ، pneumoniae المستخلص الكحولي والكلوروفوروي للجذور تأثيرا تشيطيا جيدا في أنواع الجراثيم الم ذنكورة

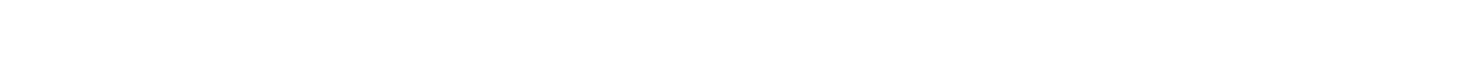

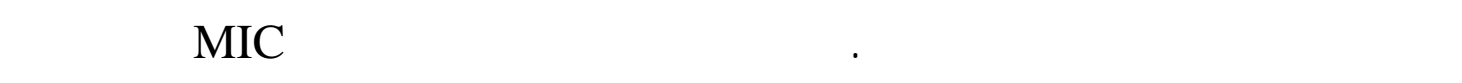
القانل الأنس MBC لمستخلصات الجذور على أنواع الجراثيم المذكورة أعلاه.

\begin{abstract}
In the present study ethanol and chloroform extracts from different parts of Capparis spinosa (flowers, fruits, leaves and roots) were screened for antibacterial activities against Staphylococcus aureus, Bacillus subtilis, Klebsiella pneumoniae, Pseudomonas aeruginosa and Proteus vulgaris, ethanol and chloroform extracts from C. spinosa roots showed good inhibitory effects against tested bacteria compared with standard antibiotics, meanwhile no clear activity was detected using both extracts from flowers, fruits and leaves against the test bacteria. Minimum inhibitory concentrations MIC and minimum bactericidal concentrations $\mathrm{MBC}$ of root extracts were determined against the tested bacteria.
\end{abstract}




\section{Introduction}

A large portion of the world population, especially in developing countries depends on the traditional system of medicine for a variety of diseases. Several hundred genera are used medicinally, mainly as herbal preparations in the indigenous systems of medicine in different countries and are sources of very potent and powerful drugs which have stood the test of time and modern chemistry has not been able to replace most of them. The World Health Organization (WHO) reported that $80 \%$ of the worlds population rely chiefly on traditional medicine and a major part of the traditional therapies involve the use of plant extracts or their active constituents [1]. Due to the indiscriminate use of antimicrobial drugs the microorganisms have developed resistance to many antibiotics. This has created immense clinical problem in the treatment of infectious diseases [2]. In addition to this problem, antibiotics are sometimes associated with adverse effects on host which include hypersensitivity, depletion of beneficial gut and mucosal microorganisms, immunosuppressant and allergic reactions [3]. Therefore there is a need to develop alternative antimicrobial drugs for the treatment of infectious diseases. Medicinal herbs represent a rich source from which novel antibacterial and antifungal chemotherapeutic agents may be obtained.

Capparis spinosa L. (caper, caper berry, caper bush) belongs to Capparidaceae family, a biennial spiny shrub that bears rounded, rather fleshy leaves and big pinkish-white flowers, it grows wild on walls or in rocky coastal areas throughout the Mediterranean region. It is best known for its edible buds and fruit which are usually consumed pickled [4]. Capers have a sharp piquant flavor and add pungency, a peculiar aroma and saltiness to comestibles such as pasta sauces, pizza, fish, meats and salads. The flavor of caper may be described as being similar to that of mustard and black pepper. The capers strong flavor comes from mustard oil: methyl isothiocyanate (released from glucocapparin molecules) arising from crushed plant tissues [5].

C. spinosa cortex and leaves contain stachydrine and 3hydroxystachydrine, the root contains glucobrassicin, neoglucobrassicin and 4-methoxy-glucobrassicin, the crude extract of the flower buds contain 162 volatile constituents of which isothiocyanates, thiocyanates, sulphides and their oxidative products have been identified as the major components, the seeds and leaves contain glucocapparin and glucocleomin, the root bark contains stachydrine, rutic acid and a volatile substance with garlic oil [6], in addition the root barks are used as analgesic, anthelmintic, aperients, depurative, diuretic, emmenagogue, expectorant, tonic and vasoconstrictive it is used internally in the 
treatment of gastrointestinal infections, diarrhea, gout and rheumatism. Externally, it is used to treat skin conditions, capillary weakness [7].

\section{Materials and methods}

\section{Plant material}

Capparis spinosa was collected from Al-Rashidea region, Nineveh province and was identified at Department of Biology, the plant parts used (flowers, fruits, leaves and roots) were washed with distilled water and were dried at room temperature in dark then grinded to powder using an electrical blender.

\section{Preparation of extracts}

Extract preparation was carried out using two methods including all the plant parts for each method.

\section{Ethanol extracts}

Ethanol extracts were accomplished according to [8] which is modified from the basic method set by [9], and includes dissolving 40gm of sample in $400 \mathrm{ml}$ ethanol (concentration 95\%) then soaking for 24 hours, followed by filtration through several layers of gauze, the resulting filtrate was evaporated under reduced pressure using a rotary vacuum evaporator at $40^{\circ} \mathrm{C}$, the dried extract was stored in sterile bottles until further use.

\section{Chloroform extracts}

Dried and powdered samples (40-50gm) from each plant part used (flowers, fruits, leaves and roots) were extracted with chloroform $500 \mathrm{ml}$ using a soxhlet extractor for 15 hours continuously until the used solvent turned pure and colorless [10], the solvent was removed using a rotary vacuum evaporator at $40^{\circ} \mathrm{C}$ to give concentrated extract which was frozen and freeze-dried until use.

\section{Preparation of extract concentrations}

$1 \mathrm{gm}$ of each extract (ethanol and chloroform) was dissolved in $5 \mathrm{ml}$ DMSO (Dimethylsulfoxide) to give an extract $200 \mathrm{mg} / \mathrm{ml}$ and this was used as a standard concentration in providing next extenuations (100, 50, $25,12.5,6.25$ and $3.12 \mathrm{mg} / \mathrm{ml}$ ), then were sterilized by pasturalization at $62^{\circ} \mathrm{C}$. 


\section{Test bacteria}

The microorganisms used was Staphylococcus aureus, Bacillus subtilis, Klebsiella pneumoniae, Proteus vulgaris and Pseudomonas aeruginosa which all had been obtained and identified from Department of Biology, College of Science, University of Mosul.

\section{Screening for antibacterial activity}

The disc diffusion method [11] was used to evaluate the antibacterial activity. Nutrient agar was prepared in the plates as the media for the test microorganisms. One hundred filter paper discs Whatman No.1 (6mm in diameter) were sterilized at $140^{\circ} \mathrm{C}$ for one hour then impregnated with $1 \mathrm{ml}$ of each extract concentration [12]. The bacterial inoculum $\left(10^{8} \mathrm{cfu} / \mathrm{ml}\right.$ compared with McFarland tube No. 1), was spread evenly on to the surface of the Nutrient agar plates using a sterile cotton bud before the extract discs were positioned on the inoculated agar surface, antibiotic discs (Bioanalyse) $6 \mathrm{~mm}$ in diameter of Chloramphenicol 30 $\mu$ g, Cephalexin $30 \mu \mathrm{g}$, Tetracycline $30 \mu \mathrm{g}$ and Gentamycin $10 \mu \mathrm{g}$ were used as positive controls. All the plates were incubated for 24 hours at $37^{\circ} \mathrm{C}$, at the end of the period, inhibition zones formed were evaluated in $\mathrm{mm}$.

\section{Determination of MIC and MBC values}

Minimum Inhibitory Concentrations (MIC) was determined using turbidity test by adding $0.1 \mathrm{ml}$ of each extract concentration into tubes containing $9.8 \mathrm{ml}$ sterile Nutrient Broth, tubes were inoculated with $0.1 \mathrm{ml}$ of bacterial suspension, each test was done in triplicate. Tubes were incubated at $37^{\circ} \mathrm{C}$ for 24 hours O.D. was determined using a SERIES CECIL 1021, 1000 spectrophotometer at 595nm. The MIC values were taken as the lowest concentration of the extracts that showed no turbidity after 24 hours of incubation at $37^{\circ} \mathrm{C}$ [13] by comparing with the control tube which includes $9.8 \mathrm{ml}$ Nutrient Broth and $0.1 \mathrm{ml}$ of bacterial suspension in addition to $0.1 \mathrm{ml}$ from each extract concentrations.

The Minimum Bactericidal Concentration (MBC) was determined by subculture of the tubes showing no apparent growth in a sterile agar plate. The least concentration showing no visible growth on agar subculture was taken as MBC value [14]. 


\section{Result and Discussion}

The results of the present study showed that (leaves, fruits and flowers) of Capparis spinosa had no antibacterial activity using ethanol and chloroform extracts, these plant parts were eliminated and the study concentrated on the roots only which showed high antibacterial properties using ethanol and chloroform extracts, Gram positive bacteria was more sensitive towards extracts than Gram negative (Table 1), this may be attributed to the fact that Gram-negative cell wall is a multilayer structure and quite complex [15], and the role of secreted exoenzyme in defending bacteria against plant extracts [16]. Our results disagreed with [17] who reported that the aerial parts of $C$. spinosa had antibacterial activities against Gram positive and Gram negative bacteria using water, ethanol and beutanol as solvents, this may be consequence of different solvents, different types of strain, isolation area, and different assay methods, our results also disagreed with what was reported by [18] who revealed antibacterial activity of aerial parts from $C$. spinosa against Gram negative bacteria, meanwhile our study agreed with [19] who reported no inhibitory effects of $C$. spinosa aerial parts against Gram positive and negative bacteria. Our results indicated that ethanol extract of $C$. spinosa roots was more active against all test bacteria compared with chloroform extract, and Staph. aureus was more sensitive towards plant extracts than all other tested bacteria, even the least ethanol extract concentration $3.12 \mathrm{mg} / \mathrm{ml}$ was active against it, meanwhile Kleb. pneumoniae showed less susceptibility towards the extracts and was inhibited only using high concentrations of both extracts ethanol (200, 100 and $50 \mathrm{mg} / \mathrm{ml})$ and chloroform (200 and 100mg/ml) as in (Table 1, Figure 1 and 2). The main antibacterial cause of $C$. spinosa roots is due to the existence of compounds such as indole, aliphatic glucosionlates, polyprenols, flavonoids and alkaloids [20], and most of these compounds can be dissolved in ethanol better than chloroform, this may expound the suitability of ethanol extract in achieving antibacterial effects more than chloroform extract. From (Table 1) it can be seen that Staph aureus showed high sensitivity when treated with the used antibiotics (Chloramphenicol, Cefalexin, Tetracycline and Gentamycin) meanwhile Kleb. pneumoniae was less susceptible among test bacteria, generally $C$. spinosa root extracts achieved better inhibition zones against test bacteria compared with the antibiotic Gentamycin and a moderate effect compared with Cefalexin and Tetracycline, meanwhile a weak effect was obtained compared with Chloramphenicol. 
Table 1: Antibacterial activity of ethanol and chloroform extracts from Capparis spinosa roots.

\begin{tabular}{|c|c|c|c|c|c|c|c|c|c|c|c|c|}
\hline \multirow{2}{*}{ Microorganisms } & \multirow{2}{*}{ Extracts } & \multicolumn{7}{|c|}{ Extract concentration $(\mathrm{mg} / \mathrm{ml})$} & \multicolumn{4}{|c|}{ Control } \\
\hline & & 200 & 100 & 50 & 25 & 12.5 & 6.25 & 3.12 & C & CL & TE & $\mathbf{C N}$ \\
\hline Staph. aureus & $\begin{array}{c}\mathrm{E} \\
\mathrm{CH}\end{array}$ & $\begin{array}{l}22 \\
18\end{array}$ & $\begin{array}{l}18 \\
16\end{array}$ & $\begin{array}{l}16 \\
14\end{array}$ & $\begin{array}{l}13 \\
12\end{array}$ & $\begin{array}{l}10 \\
10\end{array}$ & $\begin{array}{l}9 \\
-\end{array}$ & $\begin{array}{l}8 \\
-\end{array}$ & 30 & 32 & 30 & 19 \\
\hline B. subtilis & $\begin{array}{c}\mathrm{E} \\
\mathrm{CH}\end{array}$ & $\begin{array}{l}18 \\
16\end{array}$ & $\begin{array}{l}16 \\
14\end{array}$ & $\begin{array}{l}14 \\
13\end{array}$ & $\begin{array}{l}12 \\
10\end{array}$ & $\begin{array}{c}10 \\
-\end{array}$ & - & - & 28 & 30 & 27 & 18 \\
\hline Kleb. pneumoniae & $\begin{array}{c}\mathrm{E} \\
\mathrm{CH}\end{array}$ & $\begin{array}{l}14 \\
12\end{array}$ & $\begin{array}{l}12 \\
10\end{array}$ & $\begin{array}{l}9 \\
-\end{array}$ & - & - & - & - & 20 & 22 & 28 & 16 \\
\hline Ps. aeruginosa & $\begin{array}{c}\mathrm{E} \\
\mathrm{CH}\end{array}$ & $\begin{array}{l}16 \\
14\end{array}$ & $\begin{array}{l}14 \\
12\end{array}$ & $\begin{array}{l}12 \\
10\end{array}$ & $\begin{array}{c}10 \\
-\end{array}$ & - & - & - & 24 & 24 & 32 & 17 \\
\hline Pr. vulgaris & $\begin{array}{c}\mathrm{E} \\
\mathrm{CH}\end{array}$ & $\begin{array}{l}18 \\
17\end{array}$ & $\begin{array}{l}16 \\
15\end{array}$ & $\begin{array}{l}15 \\
13\end{array}$ & $\begin{array}{l}12 \\
10\end{array}$ & $\begin{array}{c}10 \\
-\end{array}$ & - & $\begin{array}{l}- \\
-\end{array}$ & 26 & 24 & 27 & 18 \\
\hline
\end{tabular}

- : No activity, E: Ethanol extract, CH: Chloroform extract, C: Chloramphenicol, CL: Cefalexin , TE, Tetracycline, CN: Gentamycin 


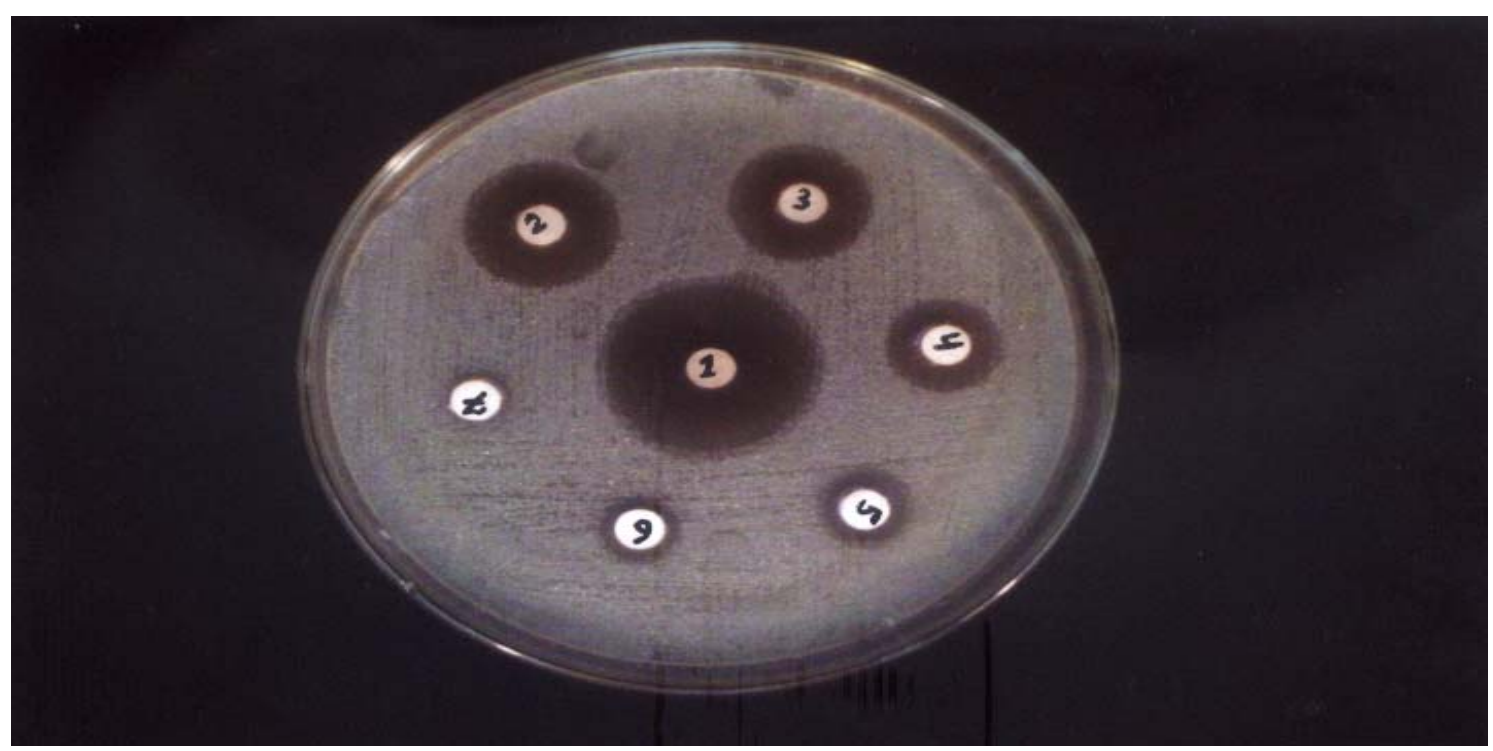

Figure 1: Effect of ethanol extract concentrations from C. spinosa roots against S.aureus $1(200 \mathrm{mg} / \mathrm{ml}), 2(100 \mathrm{mg} / \mathrm{ml}), 3(50 \mathrm{mg} / \mathrm{ml})$, $4(25 \mathrm{mg} / \mathrm{ml}), 5(12.5 \mathrm{mg} / \mathrm{ml}), 6(6.25 \mathrm{mg} / \mathrm{ml}), 7(3.12 \mathrm{mg} / \mathrm{ml})$.

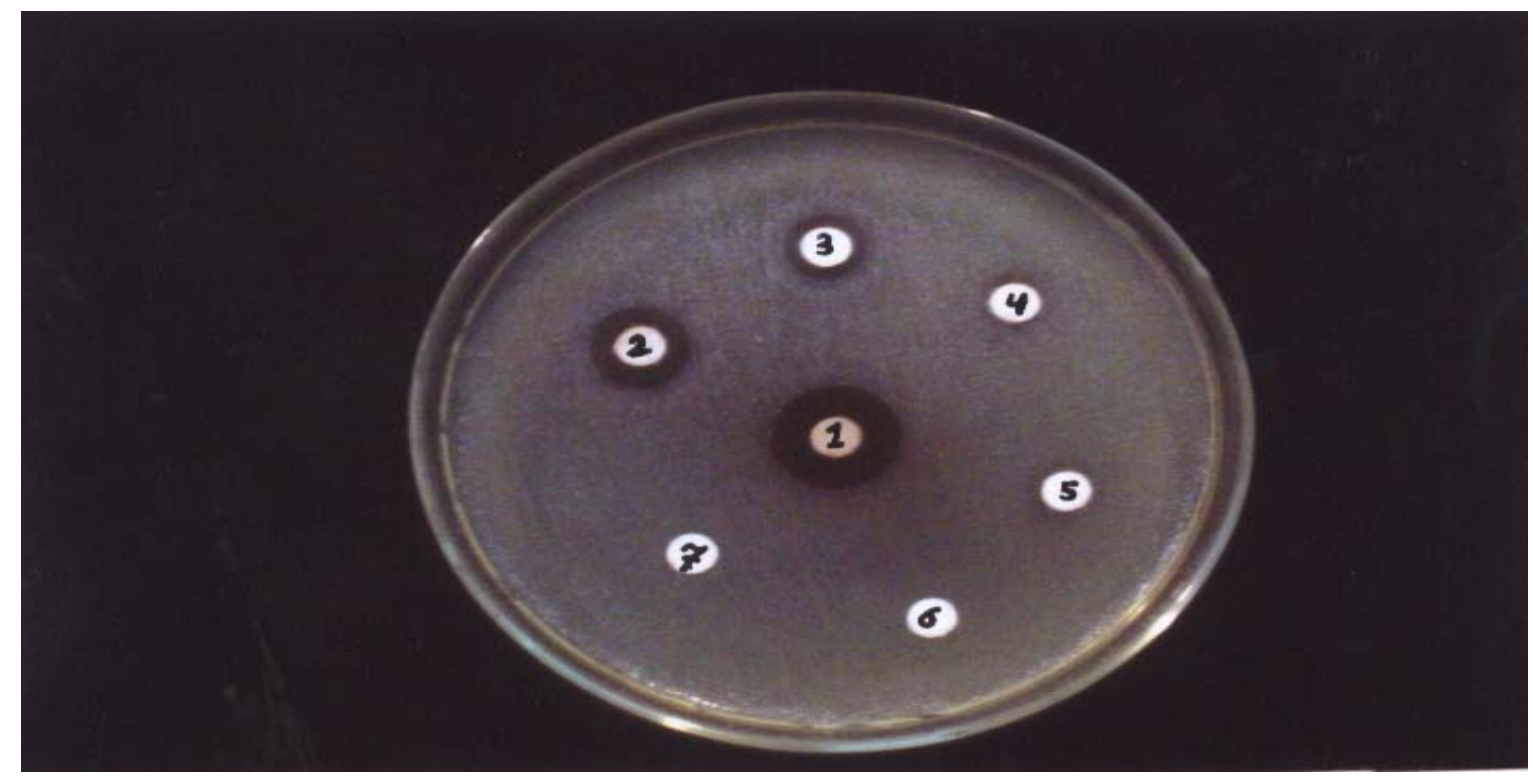

Figure 2: Effect of chloroform extract concentrations from $C$. spinosa roots against Kleb. pneumoniae $1(200 \mathrm{mg} / \mathrm{ml}), 2(100 \mathrm{mg} / \mathrm{ml}), 3(50 \mathrm{mg} / \mathrm{ml})$, $4(25 \mathrm{mg} / \mathrm{ml}), 5(12.5 \mathrm{mg} / \mathrm{ml}), 6(6.25 \mathrm{mg} / \mathrm{ml}), 7(3.12 \mathrm{mg} / \mathrm{ml})$. 
The MIC values of the ethanol and chloroform extracts from $C$. spinosa roots against test bacteria are shown in (Table 2). The MIC value of the ethanol extract against Gram positive bacteria was $0.25 \mathrm{mg} / \mathrm{ml}$ in addition to $P r$. vulgaris, and $1.0 \mathrm{mg} / \mathrm{ml}$ against Kleb. pneumoniae, meanwhile MBC values of both extracts against Staph. aureus, B. subtilis and $P r$. vulgaris were $1.0 \mathrm{mg} / \mathrm{ml}$, both extracts were unable to show MBC values against Kleb. Pneumoniae at $2.0 \mathrm{mg} / \mathrm{ml}$, these results agreed and were very close with what was reported by [21] who studied the MIC values of $C$. tomentosa roots against Gram positive and negative bacteria in addition to Candida albicans. 
Table 2: Minimum Inhibitory Concentration (MIC) \& Minimum Bactericidal Concentration (MBC) of Capparis spinosa root extracts.

\begin{tabular}{|c|c|c|c|c|c|c|c|c|c|c|}
\hline \multirow{3}{*}{$\begin{array}{c}\text { Extract } \\
\text { type }\end{array}$} & \multicolumn{10}{|c|}{ Microorganisms } \\
\hline & \multicolumn{2}{|c|}{ Staph. aureus } & \multicolumn{2}{|c|}{ B. subtilis } & \multicolumn{2}{|c|}{ K. Pneumoniae } & \multicolumn{2}{|c|}{ Ps. aeruginosa } & \multicolumn{2}{|c|}{ Pr. vulgaris } \\
\hline & MIC & MBC & MIC & MBC & MIC & MBC & MIC & MBC & MIC & MBC \\
\hline $\begin{array}{c}\text { Ethanol } \\
\text { extract }\end{array}$ & 0.25 & 1.0 & 0.25 & 1.0 & 1.0 & - & 0.5 & 2.0 & 0.25 & 1.0 \\
\hline $\begin{array}{l}\text { Chlorofor } \\
\text { m extract }\end{array}$ & 0.5 & 1.0 & 0.5 & 1.0 & 2.0 & - & 0.1 & 2.0 & 0.5 & 1.0 \\
\hline
\end{tabular}

- : No activity at $2.0 \mathrm{mg} / \mathrm{ml}$. 


\section{References}

1. World Health Organization, Herbal Gram, 28: 13-14 (1993).

2. Davis, J., Science, 264: 375-382 (1994).

3. Idose, O., Guthe, T., Willeox, R. and Deweck, A., Bulletin of WHO, 38: 159-188 (1968).

4. Rhizopoulou, S., Ioannidi, E., Alexandredesand, N. and Argiropoulos, A., J. of Arid Environments, 66: (4) 635-647 (2006).

5. Rojas, A., Hernandez, L., Pereda-Miranda, R. and Mata, R., J. of Ethnopharmacology, 35: 275-283 (1992).

6. Ahmed, Z., Rizk, A., Hammouda, F. and Seif El-Nasr, M., Phytochemistry, 11: (1) 251-256 (1972).

7. Yaniv, Z., Dafni, A., Friedman, J. and Palevitch, D., J. of Ethnopharmacology, 19: (2) 145-151 (1987).

8. Grand, A., Wondergem, P., Verpoorte, R. and Pousset, J., J. of Ethnopharmacology, 22: 25-31 (1988).

9. Verpoorte, R., Tginastoi, A., Vandoorn, H. and Svendsen, A., J. of Ethnopharmacology, 5: 221-226 (1982).

10.Fabry, W., Okemo, P. and Ansorg, M., J. Ethnopharmacology, 60: 7984 (1998).

11.Bauer, A., Kirbay, W., Sherris, J. and Turk, M., Am. J. Clin. Pathol., 45: 493-496 (1966).

12.Waage, S. and Hedin, P., Phytochemistry, 24: 243-245 (1985).

13.Kelmanson, J., Jager, A. and Staden, J., J. of Ethnopharmacology, 69: 241-246 (2000).

14.Grace, O., Letters in Appli. Microbial., 9: (3) 105-108 (1989).

15.Essawi, T. and Srour, M., J. of Ethnopharmacology, 70: 343-349 (2000).

16.Kazmi, M., Malik, A., Hameed, S., Akhtar, N. and Noor Ali, S., Phytochemistry, 36: 761-763 (1994).

17.Mahasneh, A., J. Phytotherapy Res., 16: (8) 751-753 (2002).

18.Ali-Shtayeh, M., Yaghmour, R., Faidi, Y. and Al-Nuri, M., J. of Ethnopharmacology, 60: 265-271 (1998).

19.Bonjar, G., Aghighi, S. and Nik, A., J. Biologic. Sci., 4: (3) 405-412 (2004).

20.Calis, I., Kuruuzum, A. and Ruedi, P., J. Phytochemist., 50: 12051208 (1999).

21.Buwa, L. and Van Staden, J., J. of Ethnopharmacology, 103: 139-142 (2006). 